\title{
DNA Microarray Chip
}

National Cancer Institute

\section{Source}

National Cancer Institute. DNA Microarray Chip. NCI Thesaurus. Code C18158.

An orderly array of DNA samples affixed to a support. Using robots thousands of samples can be arrayed on a sing le chip. The chip is used in various types of hybridization experiments. 